Jurnal Sistem Informasi (Journal of Information Systems). 1/13 (2017), 21-30

DOI: http://dx.doi.org/10.21609/jsi.v13i1.507

\title{
PENGARUH DUKUNGAN DAN HUBUNGAN SOSIAL TERHADAP NIAT MEMBELI PRODUK PADA SOCIAL COMMERCE
}

\author{
Puji Rahayu', Nur Fitriah Ayuning Budi², Dana Indra Sensuse ${ }^{3}$ \\ 1,2,3 e-Government Laoratory, Faculty of Computer Science, University of Indonesia, Kota Depok, Jawa \\ Barat, 16424, Indonesia \\ ${ }^{1}$ Perbanas Institute, Faculty of Information Technology, J1. Perbanas, Karet Kuningan, Setiabudi, Jakarta, \\ 12940, Indonesia
}

puji.rahayu41@ui.ac.id,nurfit90@gmail.com,dana@cs.ui.ac.id

\begin{abstract}
The emergence of social networking sites, particularly Facebook, encourages the emergence of a new paradigm in e-commerce, known as social commerce (s-commerce). S-commerce business model is currently a trend in the commercial world. Based on literature studies, we obtained two factors in the behavior and interaction of social networking site Facebook users that affect a person's intention to make purchases through social media, there is social support and relationship quality. This study aims to conduct a research on the relationship between social commerce intention, social support, and relationship quality, through a questionnaire survey conducted online to Facebook users by using purposive sampling method. The collected data from the questionnaire is then analyzed quantitatively using PLS. From the analysis and quantitative testing, it can be concluded that social commerce intention on Facebook as a medium s-commerce is affected by the relationship quality on social media itself (in this case Facebook), and is not directly affected by the social support that occurred on Facebook . However, it is known that social support on Facebook has a direct influence on the quality of the relationship quality between the user and Facebook as a medium of s-commerce.
\end{abstract}

Keywords: electronic commerce; partial least square, relationship quality; social support; social commerce intention

\begin{abstract}
Abstrak
Munculnya berbagai situs jejaring sosial, khususnya Facebook, mendorong munculnya paradigma baru dalam e-commerce yang dikenal dengan social commerce (s-commerce). Model bisnis s-commerce saat ini menjadi trend dalam dunia komersial. Berdasarkan studi literatur yang telah dilakukan, didapatkan dua faktor dalam perilaku dan interaksi pengguna situs jejaring sosial Facebook yang mempengaruhi niat seseorang untuk melakukan pembelian melalui media sosial yaitu: social support dan relationship quality. Penelitian ini bertujuan untuk melakukan confirmatory research terhadap hubungan antara social commerce intention, social support, dan relationship quality, melalui survey kuesioner yang dilakukan secara online terhadap pengguna Facebook dengan menggunakan metode purposive sampling. Data hasil kuesioner yang telah terkumpul, kemudian dianalisa secara kuantitatif dengan menggunakan partial least square (PLS). Dari analisa dan pengujian kuantitatif yang dilakukan dapat disimpulkan bahwa social commerce intention di Facebook dipengaruhi oleh relationship quality antara pembeli dan penjual, dan tidak dipengaruhi secara langsung oleh dukungan sosial dari penguna atau pembeli lainnya. Namun, diketahui bahwa dukungan sosial (social support) memiliki pengaruh langsung terhadap hubungan (relationship quality) antara pembeli dan penjual.
\end{abstract}

Kata Kunci: electronic commerce; partial least square, relationship quality; social support; social commerce intention

\section{Pendahuluan}

Perkembangan teknologi yang sangat cepat mendorong munculnya model bisnis baru yang kemudian mengubah cara konsumen berinteraksi dengan penjual. Saat ini, situs jejaring sosial menjadi salah satu trend bagi penjual dan pembeli untuk saling berinteraksi satu sama lain [1]. Trend inilah yang mendorong munculnya paradigma baru dalam $e$ commerce yang dikenal dengan social commerce (s-commerce) [1]. Stephen dan Toubia [2] mendefinisikan social commerce ini sebagai bagian dari $e$ commerce. Saat ini e-commerce memanfaatkan media internet sebagai channel interaksi dengan konsumen, social commerce spesifik pada pemanfaatan fitur dan potensi yang ada pada social 
networking seperti Facebook, Twitter, LinkedIn, dan lain sebagainya sebagai media untuk jual beli produk atau jasa.

Potensi yang ada pada situs jejaring sosial mendorong munculnya penelitian-penelitian di area e-commerce dan social commerce [1][3][4] [5]. Penelitian dari Hajli [4] mengusulkan sebuah model pengaruh dari dukungan dan hubungan sosial terhadap niat social commerce. Sedangkan, penelitian dari Kim \& Park [1], menganalisis pengaruh karakteristik social commerce terhadap kepercayaan konsumen. Penelitian lainnya menganalisis faktor-faktor yang mendorong konsumen untuk berpartisipasi dalam aktivitas social commerce [5]. Melihat penelitian-penelitian tersebut, dapat diketahui bahwa model bisnis e-commerce dan s-commerce saat ini menjadi trend dalam dunia komersial. Hal ini karena situs jejaring sosial menawarkan fitur yang mendukung perannya sebagai modern distribution channel [6].

Sebuah penelitian menganalisis tentang motivasi pengguna jejaring social (Facebook) untuk menggunakan situs tersebut [7]. Diketahui motivasi pengguna untuk menggunakan situs jejaring sosial diantaranya adalah untuk hiburan, kebutuhan kasih sayang, fashion, problem sharing, sociability, social information [7]. Dari penelitian tersebut, diketahui bahwa pada dasarnya tidak ada motivasi individu menggunakan situs jejaring sosial untuk aktivitas jual beli barang. Namun, saat ini situs jejaring sosial menjadi salah satu media untuk aktivitas jual beli barang yang digemari konsumen karena kemudahannya [8], yang diprediksi memiliki potensi penjualan hingga USD 30 milyar di tahun 2015 [9]. Hal inilah yang kemudian menarik untuk diteliti lebih lanjut, yaitu apakah ada perubahan perilaku (behavioral changes) dari konsumen untuk membeli barang dan jasa secara online dengan adanya situs jejering sosial ini.

Penelitian lainnya menganalisis kecenderungan perilaku individu untuk berbagi pengalaman berbelanja dengan temannya [10]. Aktivitas berbagi pengalaman ini menjadi salah satu cara individu untuk mendapatkan dukungan dari orang lain [11]. Dari hasil penelitian tersebut diketahui bahwa seseorang cenderung untuk mencari tahu informasi dan rekomendasi dari temannya tentang suatu produk sebelum membelinya. Lebih lanjut, tinjauan online (online review) seseorang atas suatu produk yang dijual dalam lingkungan e-commerce, khususnya dalam situs jejaring sosial merupakan strategi yang sangat ampuh untuk membangkitkan online word-of-mouth [12]. Dalam s-commerce pelanggan dapat secara langsung berinteraksi dengan penjual dari produk dan jasa tersebut. Selain itu, pelanggan tidak hanya membeli produk atau jasa di s-commerce, tetapi juga berbagi pengalaman berbelanja mereka secara langsung di s-commerce tersebut, maka pelanggan memiliki peranan yang penting di s-commerce dibandingkan dengan $e$ commerce. Oleh karena itu pengalaman seseorang dapat mempengaruhi keputusan dan perilaku seseorang untuk dalam berbelanja. Hal inilah yang kemudian dikenal sebagai salah satu strategi viral marketing, yaitu word-of-mouth (WOM) [13].

Salah satu kunci untuk memperoleh konsumen yang loyal adalah dengan membangun kepercayaan dari konsumen tersebut. Kualitas hubungan diketahui sebagai faktor kunci yang memegang peranan penting dalam kesetiaan pelanggan (customer loyalty) [14]. Sedangkan, kualitas hubungan ditentukan oleh kepercayaan (trust), kepuasan hubungan (relationship satisfaction), dan komitmen [4]. Kepercayaan telah ditekankan sebagai salah satu penentu utama loyalitas pelanggan dari berbagai literatur [15]-[16]. Sayangnya, saat ini kepercayaan (trust) menjadi isu utama dalam social commerce [17].

Saat ini diketahui bahwa masih sedikit penelitian yang membahas dan menganalisis secara dalam topik social commerce [18]. Berdasarkan penjelasan tersebut diatas, penelitian ini bertujuan untuk menganalisis lebih lanjut (confirmatory research) faktor-faktor yang mempengaruhi niat untuk membeli produk melalui situs jejaring sosial (social commerce) ditinjau dari sisi hubungan sosial dan dukungan sosial. Selain itu, penelitian ini juga bertujuan untuk membandingan faktor mana yang paling berpengaruh bagi konsumen untuk melakukan transaksi social commerce, apakah hubungan sosial atau dukungan sosial.

Saat ini salah satu media yang populer untuk memasarkan sebuah produk dan jasa adalah menggunakan sosial media. Sosial media menjadi sebuah penghubung untuk berkomunikasi antar indivi$\mathrm{du}$, baik terjadi dalam suatu negara ataupun antar negara menggunakan sebuah platform tertentu [19].

\section{E-commerce ke Social commerce}

E-commerce merupakan salah satu bentuk evolusi model bisnis yang mengadopsi teknologi Web 2.0 dengan tujuan untuk dapat meningkatkan partisipasi konsumen dan memperoleh nilai ekonomi (economic value) yang lebih besar [18]. Dari penelitian tersebut, disebutkan faktor kunci yang mempengaruhi kinerja dari platform e-commerce yang terdiri dari usability, information quality, website quality, dan playfulness [18]. Dengan adanya perkembangan teknologi media sosial dan web 2.0, memberikan kesempatan yang besar untuk mengubah bisnis model e-commerce dari product-oriented environment menjadi social and customer-oriented [20]. Stephen \& Toubia [2] menyebutkan bahwa lingkungan e-commerce yang memanfaat- 
kan web 2.0 telah mengubah kekuatan pasar (market power) dari perusahaan ke konsumen. Lebih lanjut, saat ini konsumen menjadi semakin demanding dengan adanya layanan dan aplikasi online tersebut untuk dapat berinteraksi lebih secara sosial dan interaktif [2][18]. Perkembangan teknologi inilah yang kemudian mendorong munculnya suatu inisiatif baru yang dikenal sebagai social commerce.

Social commerce merupakan kombinasi $e$ commerce dan web 2.0 [18]. Social commerce itu sendiri merupakan sebuah istilah yang multi-disciplines, termasuk didalamnya marketing, ilmu komputer, sosiologi, dan psikologi [18]. Penelitian sebelumnya menyebutkan bahwa media sosial atau web 2.0 merupakan sebuah alat marketing yang membantu dalam proses pengambilan keputusan dan perilaku belanja konsumen [18]. Dari penjelasan tersebut, social e-commerce dapat didefinisikan sebagai sebuah aplikasi online berbasis web 2.0 yang mendukung interaksi dan komunikasi kolaboratif, sehingga dapat membantu konsumen dalam proses pengambilan keputusan untuk membeli barang dan jasa secara online. Secara umum, perbedaan antara e-commerce dan social commerce terletak pada tujuan bisnis, hubungan antar konsumen, dan sistem interaksi [18]. Dalam perspektif tujuan organisasi, e-commerce bertujuan untuk memaksimalkan efisiensi dengan strategi seperti oneclick buying, pencarian produk, rekomendasi produk dan katalog online sehingga dapat diketahui perilaku online konsumen. Sedangkan dilihat dari hubungan antar konsumen, e-commerce menyediakan platform yang independen dan individual untuk satu konsumen saja, sedangkan social commerce memungkinkan adanya interaksi dan komunikasi antara satu konsumen dengan konsumen lainnya. Terakhir, dari segi sistem interaksi, e-commerce merupakan platform yang menyediakan komunikasi satu arah, dimana informasi dari seorang konsumen jarang disebar ke konsumen lainnya. Sedangkan sosial commerce mengadopsi pendekatan sosial dan interaktif yang memungkinkan satu konsumen berbagi pengalaman berbelanja dengan konsumen lainnya.

Dalam area social e-commerce, beberapa penelitian telah meneliti terkait perilaku konsumen, pengambilan keputusan, dan membangun hubungan (relationship development) [20][21]. Penelitian dari Kim \& Srivastava [21] mengidentifikasi pengaruh sosial kepada konsumen e-commerce. Penelitian tersebut menunjukkan hasil bahwa pengaruh sosial memiliki pengaruh terhadap keputusan seseorang untuk membeli produk secara online.

\section{Kualitas Hubungan (Relationship quality)}

Bisnis berkaitan erat dengan profit dan trust. Se- makin besar trust (kepercayaan) konsumen terhadap produsen berdampak pada meningkatnya profit yang bisa didapatkan oleh produsen tersebut. Dalam dunia maya, khususnya social commerce, kepercayaan menjadi sebuah hal yang utama sebelum melakukan transaksi. Kepercayaan tersebut dapat dilihat dari online reputation [18]. Konsumen akan melakukan transaksi apabila toko atau perusahaan yang menawarkan barang merupakan sebuah usaha yang dapat dipercaya. Pembeli saat ini lebih selektif dalam membeli barang secara online. Pembeli akan mencari reputasi penjual terlebih dahulu sebelum membeli [8]. Lebih lanjut, konsumen akan menjadi loyal apabila penjual memiliki hubungan yang baik dengan pembeli. Kualitas hubungan tersebut dapat mempengaruhi konsumen untuk melakukan transaksi.

Salah satu komponen penting dalam perilaku manusia bahwa masing masing individu memiliki kebutuhan untuk mengontrol, memprediksi, dan memahami lingkungan sosialnya [22]. Mereka ingin mengetahui bagaimana perilaku mereka akan mempengaruhi perilaku orang lain, dan sebaliknya. Didalam interaksi tersebut terbangun sebuah hubungan sosial yang didasari oleh kepercayaan (trust). Dari perspektif aktivitas bisnis, trust merupakan sekumpulan harapan sosial (social expectations) yang penting dan menentukan perilaku sosial seseorang, yang memungkinkan seseorang untuk merespon atau menanggapi perilaku orang lain [23].

Penelitian Celeste membuktikan adanya moderationg effect dari budaya (culture) dan mediating role dari kepercayaan (trust) didalam sebuah komunitas online dalam hubungan antara interaksi sosial dan niat untuk membeli dalam lingkungan social commerce. Penelitian menunjukkan bahwa ada tiga hal utama dalam relationship quality yaitu: trust, relationship satisfaction, dan relationship commitment [24]. Trust berkaitan dengan kepercayaan terhadap penjual. Kepercayaan menjadi hal yang sangat penting untuk membuat pembeli menggunakan jasa dan produk yang ditawarkan. Hal ini tentunya berkaitan dengan keinginan untuk melakukan pembelian kembali terhadap suatu barang. Yang perlu digarisbawahi adalah bahwa komitmen tumbuh diawali dengan trust yang kuat terhadap seorang penjual. Kualitas hubungan yang terakhir dinilai berdasarkan kepuasan terhadap layanan, produk, atau harga yang ditawarkan oleh penjual.

\section{Dukungan Sosial (Social support)}

Manusia dikenal sebagai mahluk sosial. Mahluk yang tidak bisa hidup sendirian tanpa berinteraksi dengan manusia lainnya [25]. Interaksi tersebut menjadikan adanya social support. Social support memiliki pengertian bahwa segala macam duku- 
ngan atau rasa peduli yang diberikan oleh orang terdekat, seperti keluarga, teman, dll [26].

Huang \& Benyoucef mengusulkan sebuah model social commerce yang terdiri dari empat layer, yaitu individual, conversation, community, dan commerce [27]. Layer ketiga dalam model tersebut adalah terkait dengan community building. Komunitas merupakan sekelompok orang yang bisa mendukung satu sama lain untuk mendukung pengambilan keputusan. Dari model tersebut diketahui bahwa dukungan sosial menjadi kunci penting yang mendukung fungsi bisnis dalam social commerce. Hal ini dikarenakan social support berpengaruh dalam menentukan behaviour seseorang dalam melakukan transaksi.

Dengan adanya sosial media, social support di dunia maya menjadi sebuah hal penting. Seseorang bergabung dalam sebuah komunitas atau jaringan media sosial untuk mendapatkan informasi, dan referensi berkaitan dengan sesuatu hal [28]. Informasi yang disampaikan tersebut bisa berupa pengetahuan, informasi, pujian atau keluhan terhadap suatu produk atau jasa. Pengaruh percakapan dalam sosial media bisa menjadikan sebuah produk bernilai baik atau bahkan buruk tergantung bagaimana proses berbagi pengalaman antar satu konsumen dengan konsumen lainnya secara online (electronic word of mouth). Sehingga, dapat dilihat bahwa dukungan sosial dapat mempengaruhi sisi emosional dan informasional konsumen dalam keputusan untuk membeli produk secara online.

Dalam lingkungan social commerce, calon pembeli menentukan pilihan untuk membeli produk secara online berdasarkan saran dari teman atau keluarga yang tergabung dalam komunitas sosial yang mereka percaya [24]. Oleh karena itu dapat diketahui bahwa informasi dan pengalaman belanja seseorang yang berujung pada kepercayaan terhadap informasi dan pengalaman tersebut diharapkan dapat disalurkan ke orang lain dalam suatu komunitas online. Lebih lanjut dijelaskan bahwa calon pembeli bisa mempercayai keamanan dari lingkungan online apabila semua orang yang ada dilingkungan tersebut dapat dipercayai. Sehingga dapat disimpulkan pula bahwa dukungan sosial juga mempengaruhi kualitas hubungan antar konsumen dalam komunitas online.

\section{Social commerce Intention}

Telah banyak penelitian terkait faktor faktor kunci dan kesuksesan dari social commerce [3][4][5] [18]. Beberapa penelitian menunjukkan bahwa semakin besar kepercayaan seseorang terhadap suatu vendor online mendorong niat seseorang untuk membeli secara online [29][30], membantu mempertahankan konsumen, dan rendahnya trust berdampak pada keengganan seseorang untuk mem- beli secara online [31]

Lebih lanjut, penelitian dari Kim dan Srivastava menginvestigasi pengaruh sosial sebagai penentu keputusan konsumen untuk membeli produk secara online [21]. Hasil penelitian menunjukkan bahwa pengaruh sosial berpengaruh signifikan terhadap keputusan konsumen untuk membeli produk secara online. Dari penelitian tersebut, direkomendasikan untuk menggunakan berbagai jenis aplikasi untuk dapat meningkatkan interaksi sosial, yang terdiri dari rekomendasi teman, review customers, komunikasi, dan writing and rating review. Tujuan dari adanya interaksi tersebut adalah sehingga dapat tercipta kolaborasi yang dapat membantu dalam penentuan keputusan untuk membeli barang online melalui pengalaman dari komunitas online lainnya.

Social commerce intention merupakan sebuah cara dalam mengetahui bagaimana mengantisipasi kemungkinan konsumen melakukan sesuatu aksi. Tujuan untuk memperhatikan social commerce intention adalah untuk mendapatkan keuntungan dari komunitas dan jaringan sosial. Salah satu penelitian mengatakan 'itention to use' digunakan merupakan hasil investigasi dari theory of reasoned action, theory of technology acceptance model \& theory of planned behaviour [4].

\section{Partial Least Square (PLS) dan Structural Equation Modelling (SEM)}

Partial Least Square (PLS) merupakan salah satu metode analisa data yang cukup popular dikalangan peneliti bidang sistem informasi. Metode ini merupakan metode analisa data berbasis regresi, yang dapat digunakan untuk menganalisa data dengan kondisi yang tidak normal [32]. Selain itu, PLS juga menawarkan kelebihan dapat digunakan untuk menganalisis data dengan sampel yang kecil

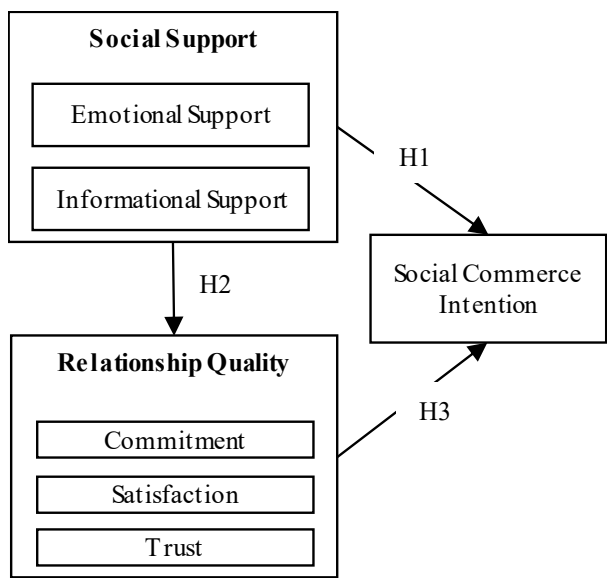

Gambar 1. Kerangka Penelitian [2] 
[32][33] dan cocok untuk penelitian berbasis confirmatory dan exploratory research [32].

Structural Equation Modelling (SEM) merupakan metode statistik yang digunakan untuk memodelkan data secara komprehensif diantara satu atau lebih independent variable dengan satu atau lebih dependent variable [34]. Salah satu kelebihan dari metode SEM adalah bebas dari measurement error. Karena dalam evaluasi korelasi antar variabel, potential error telah diperhitungkan sebelumnya dan dihilangkan. Selain itu, SEM dapat digunakan untuk menganalisa model yang sifatnya kompleks dan multidimensional. Kelebihan SEM lainnya yaitu SEM memiliki kemampuan untuk menguji hipotesis hipotesi pada level yang sesuai. Namun, dengan kelebihannya tersebut, SEM membutuhkan sampel data yang cukup besar dibandingkan dengan metode statistik lainnya.

\section{Metode Penelitian}

Merujuk kepada model yang diusulkan oleh Hajli, penelitian ini merupakan confirmatory analysis dari penelitian sebelumnya dan mengadopsi model tersebut untuk menangkap fenomena yang terjadi pada masyarakat [4]. Secara garis besar penelitian ini bertujuan untuk menganalisis perilaku dari konsumen untuk membeli barang dan jasa secara online melalui situs jejaring sosial sebagai media informasi.

Penelitian ini menggunakan kerangka penelitian yang diilustrasikan pada Gambar 1. Model hipotesis yang digunakan terdiri atas tiga komponen yaitu, Social support, Relationship quality, dan Social commerce intention. Komponen Social support terdiri atas Emotional Support dan Informational Support, sedangkan Relationship quality terdiri atas Commitment, Satisfaction, dan Trust.

\section{Hipotesis Penelitian}

\section{Dukungan sosial (Social support)}

Informasi dan pengalaman belanja seseorang yang berujung pada kepercayaan terhadap informasi dan pengalaman tersebut diharapkan dapat disalurkan ke orang lain dalam suatu komunitas online. Lebih lanjut dijelaskan bahwa calon pembeli bisa mempercayai keamanan dari lingkungan online apabila semua orang yang ada dilingkungan tersebut dapat dipercayai. Sehingga dapat disimpulkan pula bahwa dukungan sosial juga mempengaruhi kualitas hubungan konsumen dan penjual dalam komunitas online.

Berdasarkan penjelasan tersebut, maka dapat dibuat hipotesis sebagai berikut:

H1. Dukungan sosial (social support) pada situs jejaring sosial Facebook memiliki pengaruh lang-
TABEL 1

DEMOGRAFI RESPONDEN

\begin{tabular}{cccc}
\multicolumn{5}{c}{ DEMOGRAFI RESPONDEN } \\
\hline \multicolumn{3}{c}{ Usia (tahun) } & \multicolumn{2}{c}{ Mengakses situs social commerce Fa- } \\
cebook
\end{tabular}

sung terhadap niat sosial commerce (social commerce intention) pengguna.

H2. Dukungan sosial (social support) pada situs jejaring sosial Facebook memiliki pengaruh langsung terhadap kualitas hubungan (relationship quality) antara pengguna (pembeli) dan penjual.

Kualitas Hubungan (Relationship quality)

Bisnis berkaitan erat dengan profit dan trust. Semakin besar trust (kepercayaan) konsumen terhadap produsen berdampak pada meningkatnya profit yang bisa didapatkan oleh produsen tersebut. Dalam dunia maya, khususnya social commerce, kepercayaan menjadi sebuah hal yang utama sebelum melakukan transaksi.

Penelitian ini berusaha untuk menunjukkan bahwa ada tiga hal utama dalam relationship quality yaitu: trust, relationship satisfaction, dan relationship commitment.

Berdasarkan penjelasan tersebut, maka dapat dibuat hipotesis sebagai berikut:

H3. Relationship quality memiliki pengaruh langsung terhadap social commerce intention dari pengguna Facebook

Untuk menguji hipotesis yang telah dipaparkan pada bagian sebelumnya, penelitian ini menggunakan metode kuesioner yang dilakukan secara online, dimulai pada tanggal 9 November 2014 hingga 16 November 2014. Adapun untuk metode sampling dan kuesioner yang digunakan akan dijelaskan pada sub-bab dibawah ini.

Sampel Penelitian

Populasi dalam penelitian ini adalah semua pengguna situs jejaring sosial di Indonesia. Pengguna di sini meliputi semua orang yang pernah mengakses/ menggunakan situs s-commerce B2C di Facebook baik untuk tujuan membeli barang, membandingkan harga, atau sekedar mencari informasi. Jika hanya sekedar tahu saja namun belum pernah mengakses, maka tidak diikutsertakan ke dalam populasi. Demografi responden dapat dilihat pada Tabel 1. Dapat dilihat bahwa semua responden pernah mengakses situs social commerce di Facebook.

Jumlah sampel yang dianjurkan dalam melakukan penelitian dengan teknik PLS minimal 30. Dalam jangka waktu sekitar 1 minggu pengumpulan data didapatkan sampel untuk kuisioner s- 
commerce sebanyak 60. Jumlah ini sudah mencukupi untuk selanjutnya diolah dengan menggunakan teknik PLS.

\section{Instrumen Penelitian}

Data kuantitatif didapat dengan melakukan penyebaran kuisioner ke responden yang pernah mengakses s-commerce. Pengambilan sampel dilakukan secara purposive sampling di mana responden dipilih dengan menyebarkan kuesioner ke orang-orang yang dimungkinkan memenuhi kriteria responden. Kuisioner dibuat dengan menggunakan fasilitas gdocs, sehingga penyebaran kuisioner dilakukan secara online. Alasan penyebaran kuisioner secara online adalah karena hal ini cukup efisien dalam segi waktu, tenaga, dan biaya. Kuisioner disebarkan melalui e-mail, jejaring sosial seperti Facebook, Twitter, dan forum online seperti Kaskus. Agar kuisioner menuju ke target responden yang tepat sasaran, maka sebelumnya calon responden diajukan pertanyaan apakah ia pernah mengakses situs s-commerce di Facebook. Jika tidak, maka calon responden tersebut tidak perlu mengisi kuisioner. Pertanyaan kuisioner dibuat dengan menggunakan skala likert dengan merujuk pada penelitian Hajli [4].

\section{Analisis Data}

Dari hasil kuesioner yang telah terkumpul, penulis kemudian melakukan analisa terhadap data kuesioner tersebut dengan menggunakan metode PLS. PLS merupakan salah satu metode analisa data yang cukup popular dikalangan peneliti bidang sistem informasi. Metode ini merupakan metode analisa data berbasis regresi, yang dapat digunakan untuk menganalisa data dengan kondisi yang tidak normal [32].

\section{Hasil dan Pembahasan Pengukuran Model}

Pendekatan untuk menganalisa data adalah dengan mengevaluasi measurement model untuk kemudian dilakukan evaluasi structural model. Evaluasi measurement model ditujukan untuk mengevaluasi realibility dan validity, sedangkan evaluasi structural model dilakukan untuk mengevaluasi research hypotheses and model fitness. Analisis data dilakukan dengan teknik PLS dan menggunakan bantuan aplikasi SmartPLS.

Uji validitas yang dilakukan meliputi uji convergent validity dan discriminant validity. Uji convergent validity adalah uji untuk indikator apakah memang bisa menjelaskan sebuah variabel tersebut dengan cara melihat factor loading-nya. Jika factor loading bernilai dibawah 0,5 maka indikator tidak
TABEL 2

LOADING FACTORS, AVE, APLHA

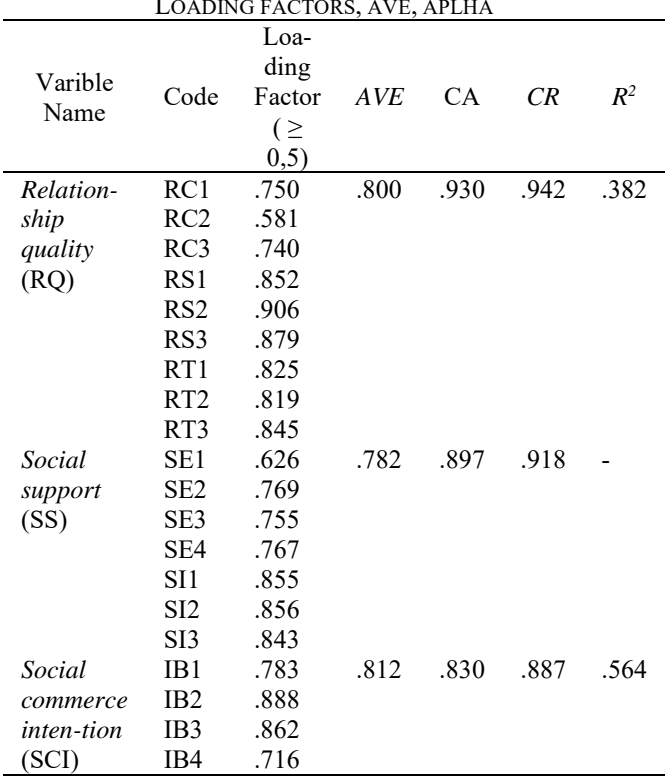

bisa menjelaskan variabel yang ada. Uji discriminant validity adalah uji untuk mencari keunikan setiap variabel, di mana hal ini kebalikan dengan uji konvergen. Jika uji konvergen untuk mencari keeratan hubungan maka uji diskriminan untuk mencari seberapa besar variabel berbeda.

Untuk uji covergent validity, indicator refleksif dapat dilihat dari korelasi antara skor item/ indikator dengan skor konstruknya. Indikator individu dianggap valid jika memiliki nilai korelasi di atas 0.50. Dari hasil uji convergent validity, diketahui bahwa nilai loading factor pada item indikator $\geq 0.50$. Pengukuran discriminant validity dapat dilihat pada $A V E(0.50)$. Dari hasil pengukuran diperoleh nilai AVE $\geq 0.5$. Sedangkan, untuk pengukuran realibility dapat dilihat pada nilai Cronbach Alpha $(\mathrm{CA} \geq 0.7)$ dan Composite Reliability (CR $\geq$ 0.7). Atas dasar tersebut, dapat disimpulkan bahwa item indikator tersebut memiliki skala validitas dan reliabilitas yang baik. Pada Tabel 2 disajikan hasil evaluasi measurement model yang terdiri dari standardized item loadings, average variance extracted (AVE), composite reliability (CR) dan Cronbach Alpha values.

Selain itu juga uji discriminant validity dengan membandingkan nilai akar kuadrat AVE dengan nilai korelasi antar variabel. Sebuah variabel dikatakan lolos uji discriminant validity jika nilai akar kuadrat AVE varibel tersebut lebih besar dari nilai korelasinya dengan variabel lain. Tabel 3 . menampilkan perbandingan nilai akar kuadrat AVE dengan nilai korelasi antar varibel. Berdasarkan tabel tersebut dapat dilihat bahwa tidak ada nilai korelasi antar variabel yang lebih besar dari 
TABEL 3

\begin{tabular}{llll}
\multicolumn{4}{l}{ PERBANDINGAN AVE DENGAN KORELASI } \\
\hline & RQ & SS & SCI \\
\hline RQ & 1.000 & & \\
SS & 0.618 & 1.000 & \\
SCI & 0.744 & 0.539 & 1.000 \\
\hline
\end{tabular}

nilai akar kuadrat dari AVE. Sehingga dapat dikatakan bahwa semua variabel lolos uji discriminant validity.

\section{Uji Model Struktural}

Tahapan ini terdiri dari dua sub tahap yaitu tahapan uji kelayakan measurement model dan tahapan uji kelayakan structural model. Uji kelayakan measurement model menggunakan uji goodness of fit. Uji hipotesis dilakukan dengan melihat kriteria sebagai berikut :

a. Nilai CR (critical ratio) $>1,96$ dengan tingkat signifikansi $\mathrm{p}<0,05$ maka hipotesis diterima

b. Nilai CR (critical ratio) $<1,96$ dengan tingkat signifikansi $\mathrm{p}>0,05$ maka hipotesis ditolak

Uji model struktural dimulai dengan melihat nilai $\mathrm{R}^{2}$ yang dimiliki oleh setiap variabel endogen sebagai kekuatan prediksi model struktural. Nilai $\mathrm{R}^{2}$ dapat dilihat pada Tabel 4 . Berdasarkan tabel tersebut nilai $\mathrm{R}^{2}$ untuk seluruh variabel endogen dapat dikatakan cukup baik karena nilai nya berada pada rentang $0.333<\mathrm{R}^{2} \leq 0.670$. Variabel endogen RQ memiliki nilai $\mathrm{R}^{2}$ sebesar 0,382 yang artinya bahwa 38,2\% variance dari relationship quality (RQ) dipengaruhi oleh variabel social support (SS), sedangkan sisanya dipengaruhi oleh faktorfaktor yang lain. Sedangkan untuk variabel endogen SCI memiliki nilai $\mathrm{R}^{2}$ sebesar 0,564 yang artinya bahwa $56,2 \%$ variance dari variabel social commerce intention (SCI) dipengaruhi oleh variabel independenya yaitu knowledge relationship quality (RQ) dan social support (SS).

Selanjutnya, uji model struktural dilakukan dengan melihat dari nilai path coeffecient, nilai t $(t-$ value) yang dihasilkan dengan menggunakan algoritma Bootsrapping untuk menentukan diterima atau tidaknya hipotesis yang diajukan.

Dari tabel 5 dapat diketahui bahwa hipotesis 2 dan 3 diterima, sedangkan hipotesis 1 ditolak. Dari hasil analisis nilai T-Statistik pada Tabel 5, dapat dilihat bahwa terdapat beberapa variabel yang berpengaruh signifikan terhadap variabel yang diobservasi. Terhadap variabel social commerce intention (SCI), diketahui bahwa hanya dipengaruhi oleh faktor relationship quality $(R Q)$. Sedangkan, variabel social support (SQ) tidak memiliki kontribusi terhadap variabel social commerce intention (SCI). Namun, diketahui bahwa variabel sosial support (SS) memiliki korelasi terhadap relationship quality (RQ).

Berdasarkan hasil analisis hubungan kausal
TABEL 4

HASIL UJI HIPOTHESIS

\begin{tabular}{lll}
\hline \multicolumn{2}{c}{ Hipotesis } & Diterima/Ditolak \\
\hline Hipotesis 1 SS & Social support $\rightarrow$ S- & Ditolak \\
$\rightarrow$ SCI & commerce Intention & \\
Hipotesis 2 SS & Social support $\rightarrow$ & Diterima \\
$\rightarrow$ RQ & Relationship quality & \\
Hipotesis 3 & Relationship quality & Diterima \\
RQ $\rightarrow$ SCI & $\rightarrow$ S-commerce & \\
& Intention & \\
\hline
\end{tabular}

antar variabel laten pada uji model struktural menggunakan PLS maka diperoleh hasil hipotesis sebagai berikut ini:

H1. Dukungan sosial (social support) pada situs jejaring sosial Facebook tidak memiliki pengaruh langsung terhadap niat social commerce (social commerce intention) pengguna.

Penelitian ini tidak membuktikan bahwa dukungan sosial (sosial support) memiliki pengaruh langsung terhadap social commerce intention di situs jejaring sosial Facebook. Hipotesis ini bertentangan dengan penelitian yang dilakukan oleh Hajli [4]. Dalam hal ini, bukan berarti pelanggan scommerce Facebook tidak memiliki kecenderungan untuk berbagi pengalaman berbelanja di situs tersebut dengan temannya. Namun, review dan rekomendasi dari orang lain (teman) di Facebook belum bisa dijadikan referensi utama seseorang dalam membeli produk secara online melalui social commerce Facebook. Hal ini dikarenakan masih diragukannya kebenaran dan kredibilitas review atau rekomendasi yang diberikan oleh orang lain di Facebook benar dan kredibel. Terlebih lagi dengan fitur Facebook yang masih memungkinkan seseorang untuk membuat akun palsu, sehingga belum tentu rekomendasi dan review yang diberikan oleh orang lain benar. Ada kemungkinan review yang diberikan oleh orang lain bertujuan untuk menarik pembeli, padahal mungkin pemberi review tersebut belum pernah membeli barang tersebut sehingga tidak sesuai dengan aslinya. Selain itu, juga dimungkinkan review atau rekomendasi tersebut bersifat menjatuhkan kredibilitas sesame penjual di bisnis social commerce, mengingat kompetisi bisnis saat ini semakin ketat.

H2. Dukungan sosial (social support) pada situs jejaring sosial Facebook memiliki pengaruh langsung terhadap kualitas hubungan (relationship quality) antara pengguna (pembeli) dan penjual.

Penelitian ini membuktikan bahwa dukungan sosial (sosial support) memiliki pengaruh terhadap kualitas hubungan antara pembeli dan penjual di situs jejaring sosial Facebook. Hipotesis ini sesuai dengan penelitian yang dilakukan oleh Hajli [4]. Dalam hal ini, tentunya dukungan sosial yang diberikan kepada seseorang memiliki tingkat kebenaran, akurasi, dan kredibilitas yang baik. Seseorang meyakini kebenaran dan kredibilitas penjual dari orang lain yang mereka percaya dalam berbagi 
TABEL 5

HASIL UJI MODELSTRUKTURAL

\begin{tabular}{|c|c|c|c|c|}
\hline HP & Path & $\begin{array}{c}\text { Path } \\
\text { Coeffecient }\end{array}$ & $\begin{array}{l}\text { T Stat } \\
\geq 1.96\end{array}$ & Sig Level \\
\hline H1 & $\begin{array}{c}\mathrm{SS} \\
\rightarrow \\
\mathrm{SCI}\end{array}$ & 0.129 & 1.226 & Tidak Significant \\
\hline $\mathrm{H} 2$ & $\begin{array}{c}\mathrm{SS} \\
\rightarrow \\
\mathrm{RO}\end{array}$ & 0.618 & 9.034 & Significant \\
\hline $\mathrm{H} 3$ & $\begin{array}{c}\mathrm{RQ} \\
\overrightarrow{\mathrm{SCI}}\end{array}$ & 0.665 & 6.813 & Significant \\
\hline
\end{tabular}

pengalaman belanja di situs social commerce Facebook. Sehingga, dukungan sosial dari orang yang dipercaya, baik yang sifatnya informasional dan emosional, berdampak pada kualitas hubungan antara pembeli dan penjual dalam bisnis social commerce.

H3. Kualitas hubungan (relationship quality) pada situs jejaring sosial Facebook memiliki pengaruh langsung terhadap niat sosial commerce (social commerce intention) pengguna.

Penelitian ini membuktikan bahwa kualitas hubungan (relationship quality) memiliki pengaruh langsung terhadap kualitas hubungan antara pembeli dan penjual di situs social commerce Facebook. Hipotesis ini sesuai dengan penelitian yang dilakukan oleh Hajli [4]. Hal ini dapat dipahami dengan sangat baik bahwa dengan adanya kepercayaan, kepuasan, dan komitment yang baik dari pembeli, dapat meningkatkan niat mereka untuk membeli produk, baik sebagai first customer maupun repeat customer, secara online di situs social commerce Facebook. Semakin banyak pembeli yang memiliki hubungan yang baik dengan penjualnya, makan semakin besar reputasinya di mata pembeli (konsumen). Hal ini mendukung penelitian sebelumnya penelitian yang menunjukkan bahwa semakin besar kepercayaan seseorang terhadap suatu vendor online mendorong niat seseorang untuk membeli secara online [29][30] dan membantu mempertahankan konsumen [35].

\section{Kesimpulan}

Dari variabel-variabel yang diobsevasi, yaitu dukungan sosial (social support), kualitas hubungan (relationship quality), dan niat untuk social commerce (social commerce intention), diketahui bahwa hanya faktor kualitas hubungan (relationship quality) yang memiliki pengaruh positif dan signifikan terhadap niat untuk membeli online melalui situs social commerce Facebook. Dalam penelitian ini diketahui bahwa dukungan sosial (social support) tidak memiliki pengaruh secara langsung terhadap social commerce intention, namun memiliki pengaruh langsung terhadap kualitas hubungan (relationship quality) yang meliputi kepercayaan, komitmen, dan kepuasan pembeli terhadap penjual di situs social commerce Facebook. Oleh karena itu, dapat disimpulkan bahwa meskipun dukungan sosial memiliki tidak memiliki dampak secara langsung, namun dukungan sosial cukup memiliki pengaruh dalam membangun kualitas hubungan antara pembeli dan penjual yang pada akhirnya mempengaruhi niat pembeli untuk membeli produk secara online melalui situs social commerce Facebook.

\section{Referensi}

[1] Gatautis, R., \& Medziausiene, A. (2014). Factors Affecting Social commerce Acceptance in Lithuania. Procedia - Social and Behavioral Sciences, 110(2013), 1235-1242. doi:10.1016/j.sbspro.2013.12.970

[2] Hajli, M. N. (2014). The role of social support on relationship quality and social commerce. Technological Forecasting and Social Change, 87,17-27. doi:10.1016/j.techfore. 2014.05.012

[3] Kim, S., \& Park, H. (2013). Effects of various characteristics of social commerce (s-commerce) on consumers' trust and trust performance. International Journal of Information Management, 33(2), 318-332. doi:10.1016/j. ijinfomgt.2012.11.006

[4] Zhang, H., Lu, Y., Gupta, S., \& Zhao, L. (2014). What motivates customers to participate in social commerce? The impact of technological environments and virtual customer experiences. Information \& Management. doi:10.1016/j.im.2014.07.005

[5] Kim, D. (2013). Electronic Commerce Research and Applications Under what conditions will social commerce business models survive? Electronic Commerce Research and Applications, 12(2), 69-77. doi:10.1016/j. elerap.2012.12.002

[6] Quan-haase, A., \& Young, A. L. (2010). Uses and Gratifications of Social Media: A Comparison of Facebook and Instant Messaging. Bulletin of Science, Technology and Society, 30, 350-361.

[7] Huang, Qian, Robert M. Davison, and Hefu Liu. 2014. “An Exploratory Study of Buyers' Participation Intentions in Reputation Systems: The Relationship quality Perspec-tive." Information \& Management 51(8):952-63. http://linkinghub.elsevier.com/retrieve/pii/S0 378720614001153 (November 6, 2014).

[8] Booz and Co., (2011). Turning Like to Buy Social Media Emerges as a Commerce Channel. Available at: -http://www.booz.com/media/uploads/BaC-Turning_Like_to_-Buy.pdf (accessed at 15.11.14) 
[9] Lenhart, A., \& Madden, M. (2007a, July 1). Social networking websites and teens: An overview (Report). Washington, D.C.: Pew Internet and American Life Project. Retrieved July 1, 2008, from http://www.pewinternet. org/ppf/r/198/report display.asp

[10] Ridings, C.M., Gefen, D,. (2004). Virtual community attraction: why people hang out online, J. Comput.-Mediat. Commun. 10.

[11] Duan, W., Gu, B., \& Whinston, A. B. (2008). Do online reviews matter? - An empirical investigation of panel data, 45, 1007-1016. doi:10.1016/j.dss.2008.04.001

[12] Camarero, C., \& San José, R. (2011). Social and attitudinal determinants of viral marketing dynamics. Computers in Human Behavior, 27(6), 2292-2300. doi:10.1016/j.chb. 2011.07.008

[13] T. Hennig-Thurau. (2000). Relationship quality and customer retention through strategic communication of customer skills, J. Mark. Manag. 16, 55-79

[14] Madden, M. (2009). The audience for online video-sharing sites shoots up. Washingon, D.C.: Pew Internet and American Life Project. Retrieved January 24, 2009, from http:// www.pewinternet.org/Reports/2009/13-TheAudience-for-Online-VideoSharing-SitesShoots-Up.aspx

[15] Pavlou, P.A. (2003). Consumer acceptance of electronic commerce: integrating trust and risk with the technology acceptance model, Int. J. Electron.Commer. 7, 101- 134.

[16] Lenhart, A. (2009). Adults and Social Network Websites. Washington, D.C.: Pew Internet and American Life Project. Retrieved January 24, 2009, from http://www.pewin ternet.org/Reports/2009/Adults-and-SocialNetwork-Websites.aspx

[17] D’Ambra, J., Xiao, L. (2010). An Empirical Study of Multi-dimensional Trust and Eloyalty in E-commerce in China. AMCIS 2010 Proceedings, Paper 62.

[18] Huang, Qian, Robert M. Davison, and Hefu Liu. 2014. “An Exploratory Study of Buyers' Participation Intentions in Reputation Systems: The Relationship quality Perspective." Information \& Management 51(8): 952-63.

[19] Dong, Tse-Ping, Nai-Chang Cheng, and YenChun Jim Wu. 2014. "A Study of the Social networking Website Service in Digital Content Industries: The Facebook Case in Taiwan." Computers in Human Behavior 30: 708-14.

[20] Wigand, R. T., Benjamin, R. I., and Birkland, J. Web 2.0 and beyond: implications for electronic commerce. In Proceedings of the 10th International Conference on Electronic
Commerce, Innsbruck, Austria, August 2008, ACM Press, New York, NY, 2008.

[21] Stephen, Andrew T. and Toubia, Olivier. (2009). Deriving Value from Social commerce Networks. Journal of Marketing Research, Forthcoming. Available at SSRN:

[22] Kim, Y. A., and Srivastava, J. (2007). Impact of social influence in e-commerce decision making. In Proceedings of the Ninth International Conference on Electronic Commerce , Minneapolis, MN, August 2007, ACM Press, New York, NY, 293-302.

[23] Gefen, D., \& Straub, D. W. (2004). Consumer trust in $\mathrm{B} 2 \mathrm{C}$ e-commerce and the importance of social presence : experiments in e-Products and e-Services, 32, 407-424. doi:10.1016/j. omega.2004.01.006

[24] Zucker LG. Production of trust: institutional sources of economic structure, 1840-1920. Research in Organizational Behavior 1986; 8:53-111.

[25] Ng, C. S. (2015). Information \& Management Intention to purchase on social commerce websites across cultures: A cross-regional study. Information \& Management, 50(8), 609-620. doi:10.1016/j.im.2013.08.002

[26] Tahmasbipour, N., and a. Taheri. 2012. "A Survey on the Relation Between Social support and Mental Health in Students Shahid Rajaee University." Procedia - Social and Behavioral Sciences 47: 5-9.

[27] Frisch, Johanna U., Jan a. Häusser, Rolf van Dick, and Andreas Mojzisch. 2014. "Making Support Work: The Interplay between Social support and Social Identity." Journal of Experimental Social Psychology 55: 154-61. Wellman, Barry et al. 1996. "Computer Networks as Social Networks: Collaborative Work, Telework, and Virtual Community." Annual Review of Sociology 22(1): 213-38.

[28] Gefen D. (2000). E-commerce: the role of familiarity and trust. Omega: The International Journal of Management Science 28(6): 725-37.

[29] Jarvenpaa SL. (1999). Tractinsky N. Consumer trust in an internet store: a cross-cultural validation. Journal of Computer Mediated Communication 5(2):1-35

[30] Honman DL, Novak TP, Peralta M. (1999). Building consumer trust online. Communications of the ACM 42 (4):80-5.

[31] Chin, W.W., Marcolin, B.L., Newsted, P.R., (2003) A partial least squares latent variable modeling approach for measuring interaction effects: results from a Monte Carlo simulati on study and an electronic-mail emotion/ adoption study, Inf. Syst. Res. 14 189-217. 
30 Jurnal Sistem Informasi (Journal of Information Systems), Volume 13, Issue 1, April 2017

[32] Ringle, C.M., Sarstedt, M., Straub, D.W., (2012) Editor's comments : a critical look at the us e of PLS-SEM in MIS quarterly, MIS Q. 36 iii-xiv.

[33] Ullman, J. B. (2006). Structural Equation Modeling : Reviewing the Basics and Moving Forward, 87(1), 35-50.
[34] Reichheld FF, Schefter P. (2000). E-loyalty: your secret weapon on the web. Harvard Business Review 78:105-13. 